\title{
Population dynamics of Brachionus calyciflorus (Rotifera: Brachionidae) in waste water from food-processing industry in Mexico
}

\author{
Raymundo Alfredo Arévalo Stevenson, S.S.S. Sarma* and S. Nandini ${ }^{1}$ \\ I Carrera de Biología, UNAM Campus Iztacala, AP 314 CP 54000, Los Reyes, Iztacala, Tlanepantla, Edo. de México, \\ México. Telefax: +52 (5) 623 1212, E-Mail: sarma@ @ervidor.unam.mx \\ *Corresponding author.
}

Received 26-IX-1997. Corrected 15-IV-1998. Accepted 29-IV-1998.

\begin{abstract}
Waste water from Mexico's largest food processing industrial sector (based on maize, nejayote water) was used for growing Brachionus calyciflorus isolated from Lake Chapultepec in the Federal District of Mexico (D.F.). Nejayote water wa collected from Colonia Providencia, D.F. Experiments were conducted at $25^{\circ} \mathrm{C}$ in $25 \mathrm{ml}$ capacity vials with $20 \mathrm{ml}$ of medium into which we introduced B. calyciflorus at an initial density of 1 ind $\mathrm{ml}^{-1}$. The experimental design consisted a total of 33 test vessels ( 2 food combinations $X 5$ densities $X 3$ replicates $=30$ plus 3 replicates a controls that contained only algae). Experiments were terminated after day 16 . Waste water in original concentration did not support rotifers. However, when diluted to 5 concentrations (ranging from $2 \%$ to $32 \%$ and $\mathrm{pH}$ adjusted to 7.0), rotifer density increased with increasing concentration of waste water. Green algae (at constant density of $2 \mathrm{X}$ $10^{6}$ cells ml ${ }^{-1}$ of Chlorella) in combination with waste water resulted in a higher abundance of rotifers only at higher concentrations (above $8 \%$ ) of waste water. The maximum peak density of rotifers $\left(238 \pm 50 \mathrm{ind} \mathrm{ml}^{-1}\right.$ ) was obtained at $16 \%$ dilution of waste water and with addition of Chlorella. The rate of population increase per day (r) (mean \pm SD) varied from $0.355 \pm 0.059$ to $0.457 \pm 0.048$ depending on food combination and concentration.
\end{abstract}

Key words: Rotifer, Brachionus, waste water, population growth, Mexico.

Maize, particularly in the form of tortilla (a kind of thin-plate like soft dry bread) is one of the most important components in the diet of the Mexican population. Tortilla industry ranges from large scale (up to 50 tons per day) to cottage level production (about $700 \mathrm{kgs}$ per day) (Durán de Bazúa 1988). More than $95 \%$ of the tortilla industry in Mexico utilizes maize (and the rest utilizes wheat). For preparing tortilla by the traditional method called nixtamalization (lime-steeping of corn), the maize seeds are pre-boiled in water with lime. This process partly hydrolizes the hard seedcoat and turns the seeds into soft easily crushable material to form dough for tortilla manufacture. During this process of boiling, a number of organic (both particulate and dissolved) substances including proteins, carbohydrates and lipids are lost into the water, resulting in an organically rich medium (Pedroza 1985).

Rotifers are known to utilize particulate organic matter directly (Pourriot 1965) and dissolved organic matter via bacteria and protozoa (Arndt 1993). They thus form an important link 
in the aquatic food chain, particularly in transfering energy from lower to higher trophic levels. A number of workers have obtained high production of rotifers (up to 500 ind $\mathrm{ml}^{-1}$ ) in outdoor aquacultural practices using piggery wastes and liquid organic wastes (Jhingran 1991).

Rotifers of the genus Brachionus have been widely used as starter food for rearing larval fish and crustaceans in aquaculture (Lubzens $e t$ al. 1989), indicators of pollution (Sladecek 1983) and as bioassay organisms (Snell and Janssen 1995). They have also been included as standard bioassay organisms by the American Society of Testing and Materials in the USA (Anon. 1991). Since the waste water of tortilla industry (known as nejayote water) is rich in organic matter, we aimed at testing its suitability for growing rotifers.

\section{MATERIALS AND METHODS}

The rotifer Brachionus calyciflorus (average adult length excluding spines $=185 \pm 12 \mu \mathrm{m}$ ) was originally isolated from Lake Chapultepec (Mexico City) and successfully cultured in the laboratory using the single-celled green algae (Chlorella vulgaris, average cell diameter: 5.48 $\pm 1.21 \mu \mathrm{m}$ ) as the exclusive food (Sarma et al. 1997). Chlorella was mass cultured using Bold Basal medium (Borowitzka and Borowitzka 1988).

Our stock as well as mass cultures of rotifers were maintained in EPA medium (Anon. 1985) and routinely fed daily the green algae at a density of approximately $2 \times 10^{6} \mathrm{cells} \mathrm{ml}^{-1}$. Although in our routine cultures we were able to obtain rotifers at a density of about 100 ind ml$^{-1}$; we generally maintained the population below 50 ind $\mathrm{ml}^{-1}$ in order to reduce the possibility of male production. For regular feeding as well as for experiments, we used log phase algae, centrifuged at $4000 \mathrm{rpm}$, rinsed in distilled water and resuspended in EPA medium. The density of algae was estimated using a haemocytometer.

For obtaining a constant source of waste water from tortilla processing industry, we selected a site (Street: Estado de Zacatecas and Estado de Morelos, Colonia Providencia) in the Federal District of Mexico which regularly receives the nejayote water. Every alternate day waste water was collected from the same site and stored in a refrigerator for the experiments. We did not use waste water which was stored for more than 2 days. Since the initial $\mathrm{pH}$ of the nejayote water was as high as 9.0 due to high levels of lime (which does not support rotifer growth (Mitchell and Joubert 1986)), it was brought down to 7.0 by the addition of diluted $\mathrm{HCl}$. This process resulted in some precipitation at the bottom of the vessel, which was siphoned off. Since Brachionus does not feed effectively on particles larger than $20 \mu \mathrm{m}$ in size (Pourriot 1965), we filtered this water using $20 \mu \mathrm{m}$ mesh and the supernatant was diluted as required. This process also helped in removing most ciliates in the waste water. Once adjusted, the $\mathrm{pH}$ of the medium did not vary over a $24 \mathrm{~h}$ period. Based on preliminary tests it was observed that $B$. calyciflorus did not grow well directly on the waste water at its original concentration. We therefore diluted this water (using EPA medium) to various concentrations up to $32 \%$ (=68\% dilution) which permitted the rotifers to grow for a reasonable period. To estimate the growth of $B$. calyciflorus, we chose 5 concentrations of the waste water viz. $2,4,8,16$ to $32 \%$. Growth of the rotifer on the waste water was tested, both with and without an additional food source (Chlorella at $2 \times 10^{6}$ cells $\mathrm{ml}^{-1}$ ).

For experiments, we used $25 \mathrm{ml}$ capacity transparent vials containing $20 \mathrm{ml}$ of the waste water at the desired concentration and combination of waste water. All experiments were conducted in thermostatically controlled waterbaths set at $25^{\circ} \mathrm{C}$. The initial $\mathrm{pH}$ of the medium was adjusted to 7.0. For each dilution of waste water, we used 3 replicates. In combinations where alga was used as an additional food source, its concentration was kept at $2 \times 10^{6}$ cells $\mathrm{ml}^{-1}$. Thus, the experimental design consisted of 33 test vessels ( 2 food combinations $X$ 5 densities $X 3$ replicates $=30$ plus 3 replicates as control which contained only algae at the same density). Into each of the test vessels, we 
introduced B. calyciflorus at a density of 1 ind $\mathrm{ml}^{-1}$. The initial population of rotifers, counted individually, consisted of actively reproducing females of mixed age-group obtained from a mass-culture tank during the exponential phase of their growth. The test vessels were maintained in diffuse and continuous fluorescent illumination. Aeration was provided to the test vessels in order to keep the food particles of the test medium in suspension.

For counting rotifers, we used one of the two methods: a) whole count when the density of rotifers was less than 5 ind $\mathrm{ml}^{-1}$ or, b) aliquot subsamples of $1-5 \mathrm{ml}$ volume when the density was greater than 5 ind $\mathrm{ml}^{-1}$. For each replicate, we counted at least 3 subsamples. Following the inoculation, we estimated the population density every day until most replicates completed one population cycle. Thus, the experiment was terminated after day 16. Everyday, after estimating the population density, rotifers from all replicates were transferred to fresh medium with appropriately diluted waster water and food combination.

For estimating the population density, we counted only live female rotifers. Population density of rotifers was expressed as number per ml. For estimating the population growth rate (r) of rotifers, we used the following formula:

$$
\begin{aligned}
& r=\left(\ln N_{t}-\ln N_{o}\right) / t \\
& \text { where } \\
& N_{0}=\text { initial population density } \\
& N_{t}=\text { Population density after the time } t \\
& t=\text { time in days }
\end{aligned}
$$

\section{RESULTS}

In general the density of Brachionus calyciflorus increased with increasing concentration of waste water in the medium. The population density of the rotifers grown in waster water with addition of algae showed a similar trend (Figs $1 \& 2$ ). An increase in the proportion of waste water in the medium beyond $16 \%$ did not support high population density of rotifers.
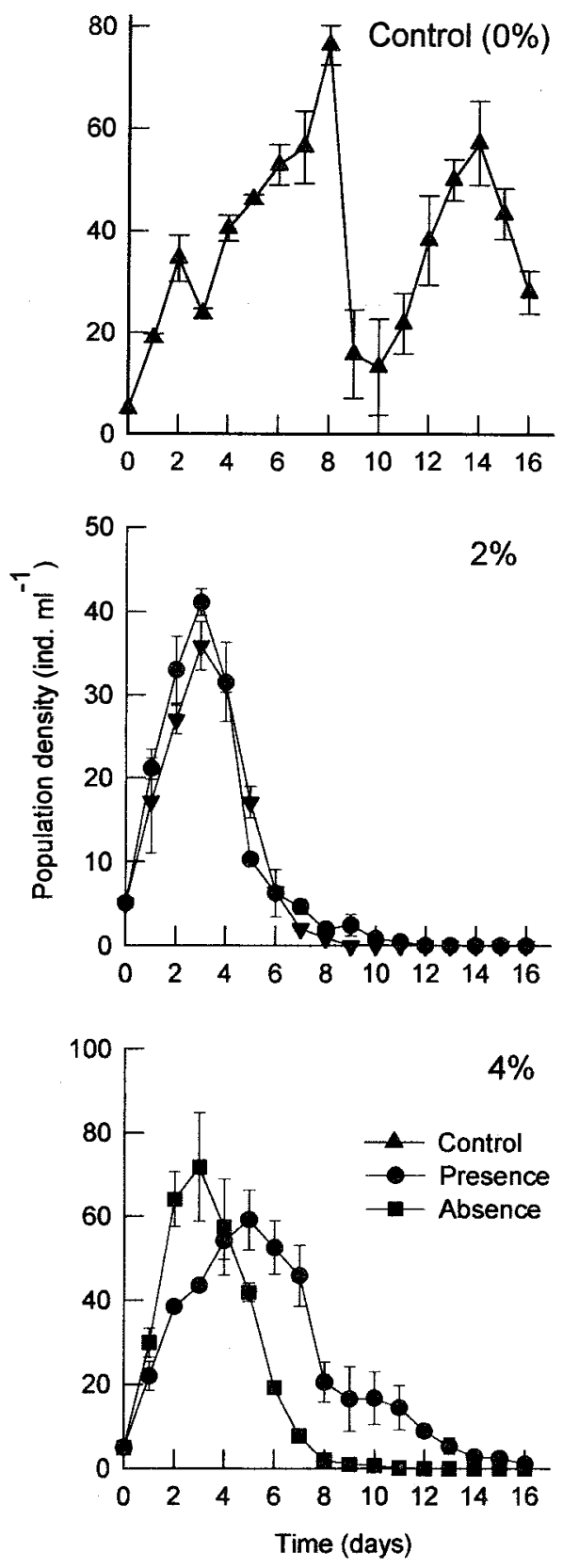

Fig.1. Population growth of the rotifer B. calyciflorus in relation to different concentrations of waste water and in the presence and absence of the algae Chlorella (at $2 \times 10^{6}$ cells $\mathrm{ml}^{-1}$ ). Shown are the mean $\pm \mathrm{SE}$ values based on three replicate recordings. Concentration of nejayote water is expressed in percentage. 

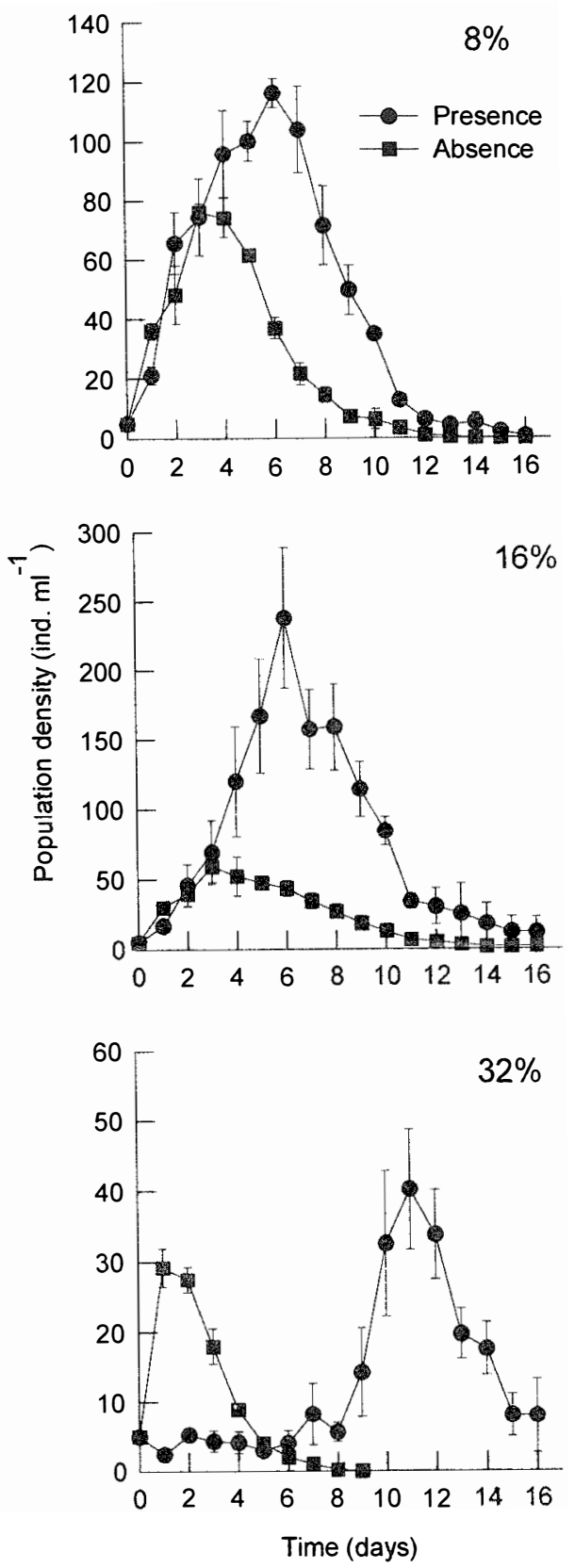

Fig.2. Population growth of the rotifer $B$. calyciflorus in relation to different concentrations of waste water and in the presence and absence of the algae Chlorella (at $2 \times 10^{6}$ cells $\mathrm{ml}^{-1}$ ). Other details as in Fig. 1.
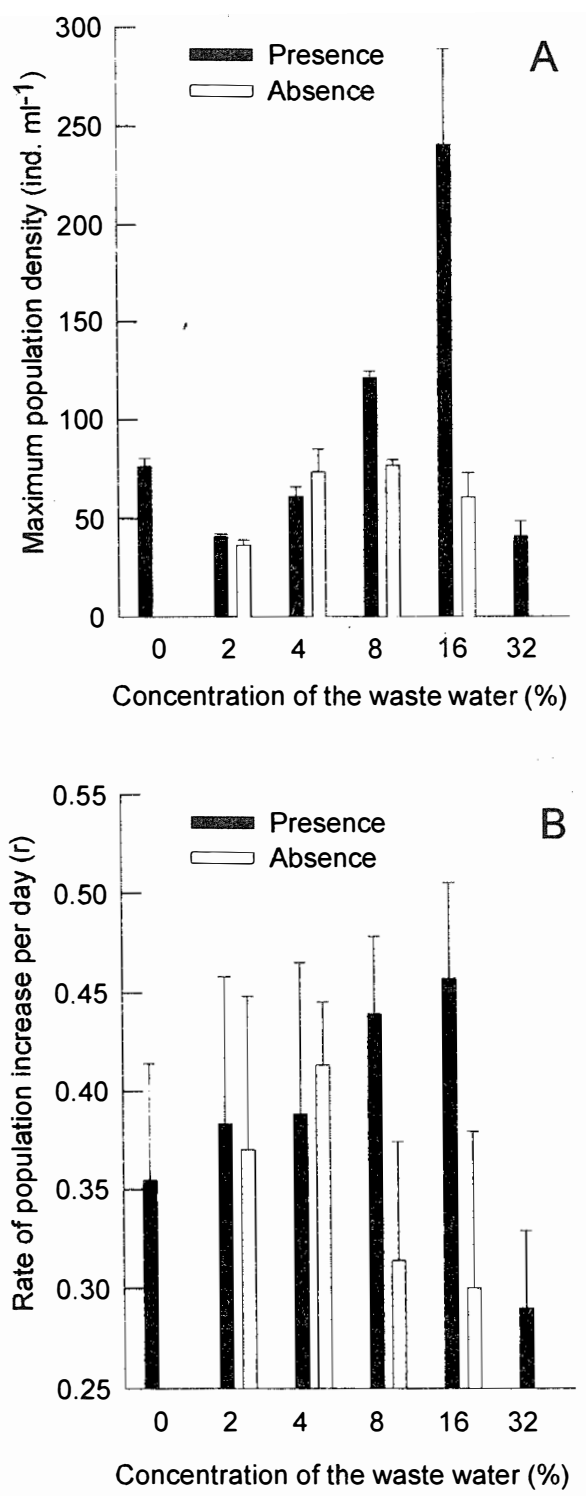

Concentration of the waste water (\%)

Fig.3a. Maximum population density reached by Brachionus calyciflorus in the presence and absence of the algae Chlorella (at $2 \times 10^{6}$ cells ml $^{-1}$ ) at different concentrations of the waste water. Shown are the mean \pm SE values based on three replicate recordings.

Fig. 3b. Rate of population growth per day (r) of Brachionus calyciflorus in the presence and absence of the algae Chlorella (at $2 \times 10^{6}$ cells ml $^{-1}$ ) at different concentrations of the waste water. Shown are the mean \pm SE values based on three replicate recordings. 
The influence of algal food was strongly evident in media with higher percentage of waste water. The maximum peak density of rotifers $\left(241 \pm 48\right.$ ind ml$\left.^{-1}\right)$ was obtained at $16 \%$ dilution of waste water and with addition of Chlorella (Fig. 3a). This variable was significantly affected by the food combination and the concentration of waste water and their interaction ( $\mathrm{P}<0.001,2$-way ANOVA).

The rate of population increase per day (r) varied from $0.355 \pm 0.059$ to $0.457 \pm 0.048$ depending on food combination and concentration (Fig. $3 b$ ). The $r$ value was significantly affected by both, the addition of algae in the medium and the concentration of waste water ( $\mathrm{P}$ $<0.001,2$-way ANOVA). The interaction of food concentration and combination also had a significant impact on the population growth rate ( $\mathrm{P}<0.001,2$-way ANOVA). The influence of algal food on the rate of population increase was not significant at $2 \%$ and $4 \%$ concentrations of the waste water $(\mathrm{P}>0.05$, F-test).

\section{DISCUSSION}

Our study confirmed the presence of utilizable form of organic matter in the nejayote water since rotifers grew well in the absence of algae. We analyzed the waste water directly for the presence of zooplankton particularly rotifers. We did not notice any zooplankton (except some ciliates) suggesting that the nejayote water as such is not suitable for growing rotifers. This was evident from the Fig. 2 in which when the waste water concentration was $16 \%$ or $32 \%$, rotifers did not maintain a population beyond a few days. One of the main reasons why nejayote water cannot be directly used is the high concentration of particulate organic matter. At high concentration of particulate matter, generally, the feeding and conversion efficiencies decrease (Downing and Rigler 1984). Thus, when the waste water concentration was $8 \%$, the density of rotifers grown in the absence of Chlorella was $77 \pm 3$ ind $\mathrm{ml}^{-1}$, but when the concentrations were $16 \%$ and $32 \%$, the observed maximum densities $(61 \pm 12$ and $29 \pm$
3 ind $\mathrm{ml}^{-1}$, respectively) were less. The addition of algae was useful at $8 \%$ and $16 \%$ concentration. A further increase in the concentration of the nejayote water resulted in a prolonged lag phase after which, however, rotifers grew but not exactly comparable to the control with algae alone. The addition of algae at higher concentrations of waste water may have helped in absorbing or even utilizing the toxic dissolved substances (such as dissolved ammonia and other nitrogen-containing inorganic compounds) (Borowitzka and Borowitzka 1988).

The population density of Brachionus calyciflorus obtained here indicated that nejayote water at $8 \%$ concentration had utilisable organic load comparable to $2 \times 10^{6}$ cells $\mathrm{ml}^{-1}$ of Chlorella biomass. In terms of dry weight, it is equivalent to about $28.4 \mu \mathrm{g} \mathrm{ml}^{-1}$. This implied that the undiluted waste water may have readily usable organic matter higher than $355 \mathrm{mg} \mathrm{l}^{-1}$ which could have a potential to result in the production of about 1000 ind $\mathrm{ml}^{-1}$ of rotifers. Production of rotifers of this density is not uncommon under field conditions. For example, piggery wastes and farmyard manures added to the fish tanks yield rotifers at a density comparable to this (Jhingran 1991).

The rate of population increase in rotifers observed here in two food combinations and 5 densities is within the range known for this species. For example, Sarma et al. (1997) have reported $\mathrm{r}$ values for this species in the range of 0.2- 0.8 depending on the food concentration and inoculation density. In rare cases, the $r$ value of this species exceeds 2.0 (Bennett and Borass 1989).

Our findings suggest the possible utilization of waste water from tortilla industry for the production of rotifers, which can be utilized in aquaculture as starter food for rearing fish and crab larvae. Since the nutritional quality of waste water from the tortilla industry does not vary significantly (Pedroza 1985), these results may be applicable for nejayote water collected from other sites. The present study can also be a start-point for other studies such as those on nutritional aspects of rotifers produced using the nejayote water. 


\section{ACKNOWLEDGMENTS}

One of us (SSSS) is thankful to CONACyT (SNI) grant (No. 18723). RAAS thanks C. Carlos Delgado for granting study leave.

\section{RESUMEN}

Se usó aguas de desecho de la industria de la masa y la tortilla (aguas de nixtamal o nejayote) para crecer rotíferos de agua dulce, Brachionus calyciflorus. El nejayote sin dilución no permitió el desarrollo del rotífero. Sin embargo, cuando se diluyó, $B$. calyciflorus aprovechó la materia orgánica. El agua de desecho por sí misma (sin alimento algal adicional) fue comparable al agua con densidades del alga Chlorella de $2 \times 10^{6}$ células $\mathrm{ml}^{-1}$. Concentraciones de nejayote por encima del $8 \%$ no permitieron el crecimiento poblacional. Sin embargo, la presencia de alga permitió el desarrollo del rotífero a concentraciones de $8 \%$ y $16 \%$. Nuestros hallazgos indican que el nejayote puedo ser utilizado de manera efectiva para la producción de rotíferos a gran escala para la acuacultura.

\section{REFERENCES}

Anonymous. 1985. Methods of measuring the acute toxicity of effluents to freshwater and marine organisms. US Environment Protection Agency. EPA/600/4-85/013.

Anonymous.1991. Standard guide for acute toxicity tests with the rotifer Brachionus. Annual Book of ASTM Standards. Vol. 11.04, E1440, American Society for Testing and Materials, Philadelphia, Pennsylvania.

Arndt, H. 1993. Rotifers as predators on components of the microbial web (bacteria, heterotrophic flagellates, ciliates): A review. Hydrobiologia 255/256: 231-246.
Bennett, W. N. \& M. E. Borass. 1989. A demographic profile of the fastest growing metazoan: a strain of Brachionus calyciflorus (Rotifera). Oikos 55: 365-369.

Borowitzka, M. A. \& L. J. Borowitzka. 1988. Micro-algal biotechnology. Cambridge University, London. 477 p.

Downing, J. A. \& F. H. Rigler (eds.). 1984. A manual on methods for the assessment of secondary productivity in freshwaters. Blackwell Scientific, Oxford. 501 p.

Durán de Bazúa, C. 1988. Una nueva tecnología para la extrusión alcalina de maíz y sorgo. Monografia Tecnólogica 2. Universidad Nacional Autónoma de México. Mexico D. F., 71 p.

Jhingran, V.G. 1991. Fish and fisheries of India. Hindustan Publ., New Delhi, 727 p.

Lubzens, E., A. Tandler \& G. Minkoff. 1989. Rotifers as food in aquaculture. Hydrobiologia 186/187: 387-400.

Mitchell, S.A.\& H. B. Joubert. 1986. The effect of elevated $\mathrm{pH}$ on the survival and reproduction of Brachionus calyciflorus. Aquaculture 55: 215-220.

Pedroza, R. 1985. Estudio de la degradación biológica de los efluentes de la nixtamalización. Tesis de maestría, Universidad Iberoamericana. México D.F., Mexico. 75 p.

Pourriot, R. 1965. Recherches sur l'ecologie des Rotiferes. Vie Milieu (Suppl.). 21: 1-224.

Sarma, S.S.S., M. A. F. Araiza \& R. J. A. Lopéz. 1997. Influence of food concentration and inoculation density on the population growth of Brachionus calyciflorus Pallas (Rotifera). Environ. Ecol. 15: 435-441.

Sladecek, V. 1983. Rotifers as indicators of water quality. Hydrobiologia 100: 169- 201.

Snell, T. W. \& C.R. Janssen. 1995. Rotifers in ecotoxicology: a review. Hydrobiologia 313/314: 231-247. 